\title{
SKILLS AND INTERNATIONAL MIGRATION IN NEW ZEALAND
}

\author{
Manuila Tausi \\ Migration Research \\ Ministry of Business, Innovation and Employment
}

\begin{abstract}
A significant focus of immigration policy in New Zealand is on attracting and retaining skilled migrants by ensuring that they settle well in New Zealand. However, it is well known that immigration is not always a permanent decision and many migrants choose to leave after a period in the host country either returning to their home country or moving onward to another country. For the first time in New Zealand, information on migrants who were approved residence in New Zealand from 1998 to 2011 were matched with arrival and departure information from Statistics New Zealand to provide a more complete picture of their mobility patterns. This paper presents findings from this study with a focus on the skills associated with the subsequent movements of these migrants, in conjunction with the movements of the New Zealand-born population who travelled in the same period.
\end{abstract}

The full report from this study is available from the Ministry of Business, Innovation and Employment website.

\section{Introduction}

Immigration is not always a permanent decision. Many migrants choose to leave after a period in the host country, returning home or migrating onward to another country. Some of the movements between the migrants' source and host countries may involve more than one cycle. This pattern of mobility is referred to as circular migration, which is described by Agunias and Newland (2007) as “a continuing, long-term and fluid movement of people among countries that occupy what is increasingly recognised as a single economic space". Newland, Agunias and Terrazas (2008) suggested that “circular migration denotes a migrants' continuous engagement in both home and adopted [host or destination] countries; it usually involves both return and repetition”.

This paper reports from the main findings from a study (Tausi 2012), by the Ministry of Business, Innovation and Employment (MBIE), that describes the mobility patterns of migrants who took up residence in New Zealand as well as the New Zealand-born population.

For the first time in New Zealand, information on migrants who were approved residence in New Zealand from 1 January 1998 to 31 December 2011 has been matched with arrival and departure information from Statistics New Zealand over the same period. This information provides a more complete picture of migrants' mobility patterns. These mobility patterns provide a basis for understanding the extent of retention and onward migration of permanent resident migrants in New Zealand. This study also presents the mobility patterns of the New Zealand-born population who travelled in the same period. ${ }^{1}$

\section{Related Research}

In 2006, the Department of Labour conducted a quantitative analysis of its immigration database of migrants whose residence applications were approved from 1 January 1998 to 31 December 2004 (Shorland 2006). The purpose of that study was to identify migrants with particular movement patterns into and out of New Zealand, and to explore the characteristics of those who spent lengthy periods out of New Zealand. The study found a consistent loss of migrants over time; 19 percent of the 1998 cohort had left and not returned to New Zealand by the end of the study period.

Following that study, the Department of Labour produced annual long-term absence rates for permanent migrants who had been out of New Zealand for a period of six months or longer (see, for example, Department of Labour 2011).

Sanderson (2009) undertook a study of New Zealand and United Kingdom citizens in Australia using arrival and departure card information. The sample included all New Zealand and United Kingdom citizens whose first entry to Australia occurred in August 1999 to July 2002 and who stated an intention to remain in Australia for at least 12 months (including permanent settlers as well as temporary long-term residents). Their subsequent movements were recorded until the end of June 2005.

Statistical models were then used to examine the extent of onward migration and mobility and its association with characteristics of individual migrants. The results of the Australian study note that "ongoing migration patterns are far more complex than traditional migration patterns suggest, with repeat and return migration and ongoing 
mobility being an important part of the actual migration experiences”.

Stillman (2011) provided an updated picture of the economic integration of overseas-born and New Zealand-born individuals using data from the 1997-2009 New Zealand Income Survey to compare employment rates, hours worked and wages for these groups. The research also examined whether differences in observed labour market outcomes between these groups were explained by differences in characteristics such as education attainment, work experience and years in New Zealand, and whether these differences varied over time.

The big picture of New Zealand's migration flows is discussed in Department of Labour (2012). It shows that permanent and long term migration to and from New Zealand has followed a cyclical pattern over the last 60 years. Furthermore, when population size is considered, Trans-Tasman departures relative to New Zealand's population are lower now than they were in the 1970s.

Papadopoulos (2012) presents new descriptive statistics on the extent that New Zealand graduates from tertiary institutions leave New Zealand and the extent to which they return again to New Zealand. That study examines the migration outcomes, through to 2010, of a cohort of New Zealand students who completed a tertiary qualification in 2003. The author's key finding was that the likelihood that a graduate left New Zealand, and the likelihood that they were overseas seven years after completing their qualification, increased strongly with the level of the qualification.

\section{Methodology}

Appendix Table A1 shows all movements of migrants (since residence approval) and the New Zealand-born population. Most movements were of less than six months' duration, particularly departures (92 percent for migrants and 86 percent for the New Zealand-born population). The proportion of arrivals staying less than six months in New Zealand was smaller than the proportion of departures lasting less than six months out of New Zealand.

The focus of this study is on movements lasting six months or more. Therefore, for the purpose of this study, an arrival or departure is defined as a spell of six months or more in New Zealand or out of New Zealand respectively. As a result, movements of less than six months' duration have been excluded from the analysis. The six-month threshold is half the 12 months' duration based on intentions - of the Statistics New Zealand definition of permanent and long-term (PLT) migration (see, for example, Statistics New Zealand 2012). However, this is assumed to be long enough for people to set up residence in a country, rather than simply being on an extended vacation. Furthermore, the six-month threshold is consistent with the treatment of long-term absence in Shorland (2006) and Sanderson (2009).

\section{Migrants who took up residence in New Zealand}

People who wish to migrate permanently to New Zealand must apply through one of the residence streams of the New Zealand Residence Programme (NZRP): the Skilled/Business Stream, Uncapped Family Stream, Capped Family Stream, and International/Humanitarian Stream. Each stream under the programme contains various categories or immigration policies.

The Skilled/Business Stream accounts for over half of all people granted permanent residence in New Zealand (see, for example, Department of Labour 2011) with most gaining residence through the Skilled Migrant Category (SMC). The SMC is a points-based policy that allows people to gain permanent residence if they have the requisite skills, qualifications, and experience to contribute to New Zealand economically and socially. The SMC came into effect in 2003 and replaced the General Skills Policy.

The Uncapped and Capped Family and International/Humanitarian Streams are intended to:

- $\quad$ enhance the well-being of existing New Zealand residents by allowing people with whom they have family links to come to New Zealand,

- contribute to international humanitarian activities,

- fulfil other humanitarian objectives or international obligations.

Migrants are granted residence in New Zealand through the four residence streams under the NZRP. These migrants bring a variety of skills, work experience, and social and cultural values that contribute to New Zealand's economy and enrich its cultural diversity. A significant focus of current immigration policy in New Zealand is about bringing in and retaining skilled migrants, and ensuring they settle well in New Zealand.

Appendix Table A2 outlines the characteristics of migrants who took up residence in New Zealand. A total of 577,983 migrants took up residence during the study period; 161,895 moved out of New Zealand for a period of six months or more and 416,088 remained in New Zealand since taking up residence.

Most migrants (59 percent) came through the Skilled/Business Stream with a further 20 percent through the Uncapped Family Stream, 13 percent through the Capped Family Stream, and 8 percent through the International/Humanitarian Stream. The main source countries of migrants in the study period were the United Kingdom (19 percent), China (13 percent), India (10 percent), and South Africa (9 percent). About half of migrants in the study period had a student or work visa before residence approval. These were mainly migrants who were approved onshore. 
Appendix Figure A1 summarises the movements of migrants who took up residence in New Zealand during the study period, 1 January 1998 to 31 December 2011.

\section{Retention of migrants}

From the migrants who took up residence during the study period, 72 percent remained in New Zealand since taking up residence. Migrants with a previous temporary visa were more likely to remain in New Zealand (80 percent retention) than were migrants with no previous temporary visa (65 percent retention).

In terms of immigration policies in the NZRP, Figure 1 shows that migrants who took up residence through the Skilled/Business and Capped Family Streams are less likely to remain in New Zealand than those who came through the Uncapped Family and International/Humanitarian Streams.

This finding is not surprising for Skilled/Business migrants as they have the skills, qualifications, and financial resources to move more quickly to other countries with better economic outcomes. Dumont and Lemaitre (2005) observed that international migration is quite selective towards highly skilled migrants in the Organisation for Economic Co-operation and Development (OECD) countries. These highly skilled migrants "are more tuned into the international labour market (because of social capital, language skills, access to information, etc.) and have more resources to finance a move".

The lower retention rate for migrants who came through the Capped Family Stream is mainly driven by parents who return to their home countries after a period of time in New Zealand.

Figure 1: Proportion of migrants who remained in New Zealand since residence uptake by residence stream

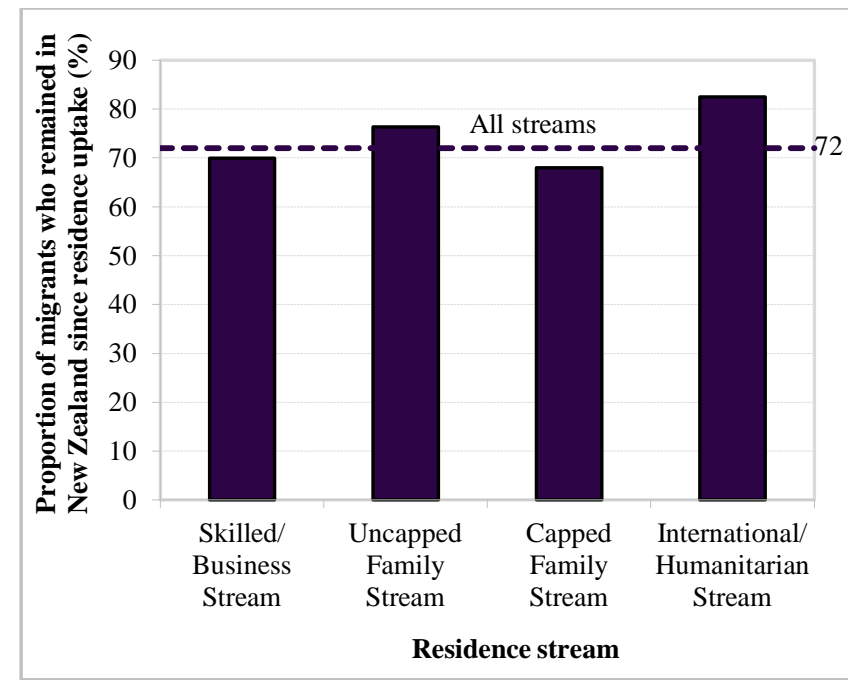

For migrants approved through the Skilled/Business Stream during the study period, 53 percent were approved through the Skilled Migrant Category (SMC), 38 percent through the former General Skills Policy, 4 percent through the Investor Category, 3 percent through the Entrepreneur Category, and 2 percent through the Residence from Work Category.

Figure 2 shows that 83 percent of the migrants who came through the SMC have remained in New Zealand since taking up residence. About half of the migrants who came through the General Skills Policy have remained in New Zealand since taking up residence. This policy ended in 2003 so most of these migrants have been in New Zealand for at least nine years and are likely to remain permanently in New Zealand. Furthermore, the lower retention rate for migrants who came through the General Skills Policy reflects the fact that they had more time to leave New Zealand than did SMC migrants.

Figure 2: Proportion of Skilled/Business migrants who remained in New Zealand since residence uptake by residence approval category

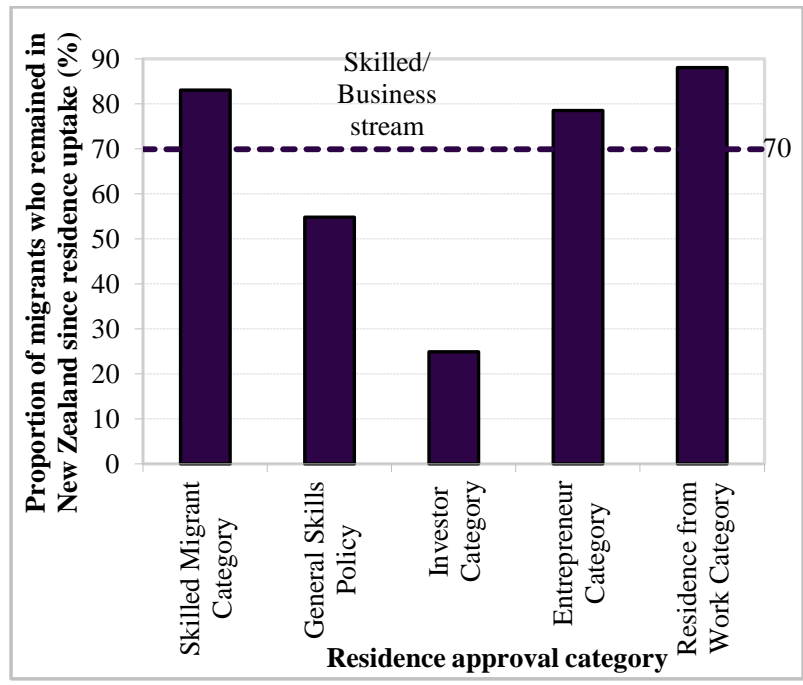

\section{Migrants who moved out of New Zealand}

Migrants come to New Zealand for various reasons: some want a better lifestyle, some want better employment opportunities or a better future for their children, and others want to live in a clean and safe environment (Masgoret, Merwood and Tausi 2009). Over time, some of these migrants decide to return home to rejoin family and friends or move on to another country.

This section looks at migrants who moved out of New Zealand for a period of six months or more after taking up residence in New Zealand. The time they spent in New Zealand until their first departure for a period of six months or more gives an indication of the time it takes migrants to make decisions about long-term settlement. It is worth noting that time until the first departure is taken from the date the resident visa is granted in New Zealand or the date of first entry into New Zealand for migrants who were outside of New Zealand when their resident visa was granted. Migrants who were outside of New Zealand when their resident visa was granted should 
make their first entry within one year after being granted the resident visa.

Some migrants spent time out of New Zealand, eventually returning by the end of the study period while others left and settled long term or permanently elsewhere. The destinations and skills of migrants who left New Zealand by the end of the study period are also highlighted.

\section{Time until the first move out of New Zealand}

The overall distribution of time until the first move out of New Zealand lasting six months or more is shown in Figure 3. Thirty percent of migrants made their first move out of New Zealand in the first six months of taking up residence. Most migrants who moved out of New Zealand in the first six months of taking up residence were approved through the Skilled/Business Stream (71 percent).

Ten percent of migrants made their first move out of New Zealand between six months and one year of taking up residence in New Zealand. Another 8 percent of migrants moved out of New Zealand 2-2.5 years after taking up residence. These migrants had remained in New Zealand until they got their permanent return visas, which give them indefinite right of re-entry into New Zealand, before making the trip out of New Zealand for a period of six months or more.

Figure 3: Distribution of time until the first move out of New Zealand for a period of six months or more

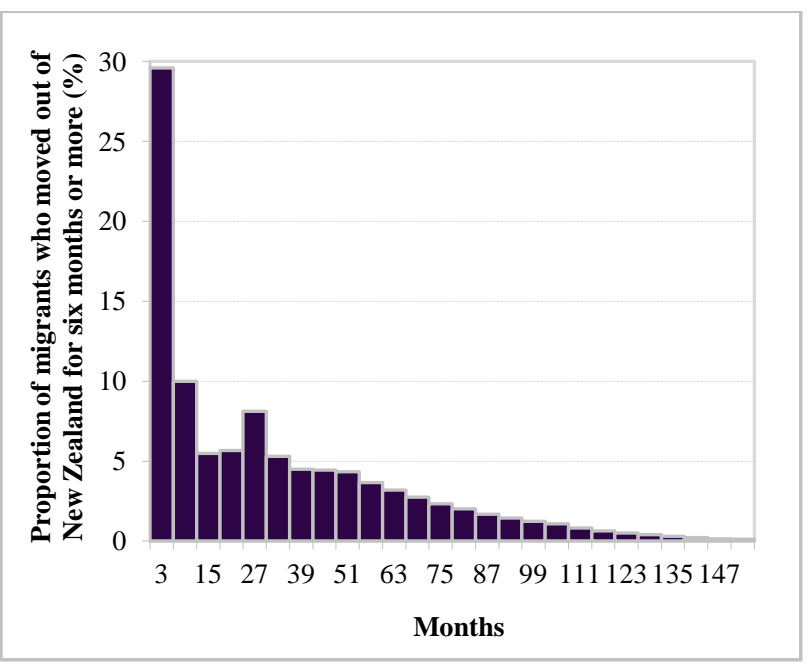

Note: Values in the horizontal axis are the mid-points (for example, 3 represents migrants leaving in the first six months, 27 represents migrants leaving in 24-30 months).

For the Skilled/Business Stream, one third of departures for six months or more occurred in the first six months of residence uptake. In particular, 23 percent of these departures occurred within the first month of taking up residence. For migrants who departed in the first month, about two-thirds, mostly skilled migrants, had not returned by the end of the study period.
Of the migrants who remained outside New Zealand following that first departure for six months or more, about one in four (25 percent) were from China, 15 percent from the United Kingdom, and 11 percent from India.

\section{Migrants who left New Zealand}

From the 161,895 migrants who moved out of New Zealand for six months or more (see Appendix Figure A1), 75 percent had not returned to New Zealand by the end of the study period. Some of these migrants had lived for six months or more outside New Zealand on more than one occasion.

Figure 4 shows that Skilled/Business migrants were more likely to remain outside New Zealand once they had the opportunity to explore other countries. Migrants approved through the Capped Family Stream were less likely to remain outside New Zealand.

Figure 4: Proportion of migrants who were still out of New Zealand given they have moved out of New Zealand for six months or more by residence stream

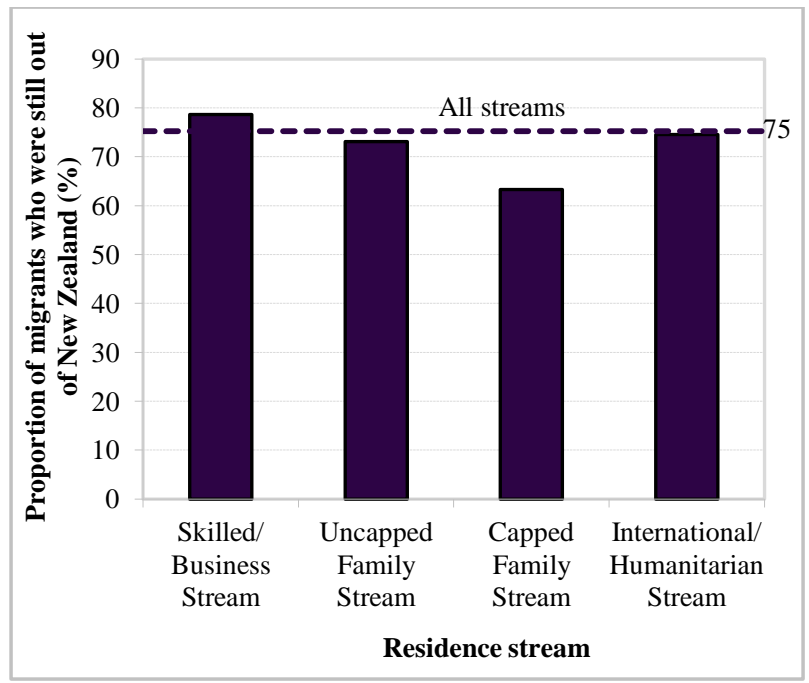

Migrants who had not returned to New Zealand took up to six trips out of New Zealand lasting six months or more before deciding not to return to New Zealand over the study period. However, most of these migrants (93 percent) had not returned to New Zealand since their first trip out of New Zealand lasting six months or more.

On average, migrants settled in New Zealand for almost three years before moving onward in their migration journey.

\section{Destinations of migrants who left New Zealand}

Of the 121,848 migrants who left New Zealand for six months or more and had not returned by the end of the study period, Australia was the main destination for 31 percent (see Figure 5). Some of these migrants may have acquired New Zealand citizenship and gained the right to reside in Australia, through the 1973 TransTasman Travel Arrangement (TTTA) whereby New 
Zealand and Australian citizens may travel, work, and live in either country without being required to apply for entry permission. This has generated some debate about migrants using New Zealand as a "back-door" route for migration into Australia (Hoadley, 2002).

Figure 5: Main destinations of migrants who left New Zealand for six months or more and had not returned by the end of the study period

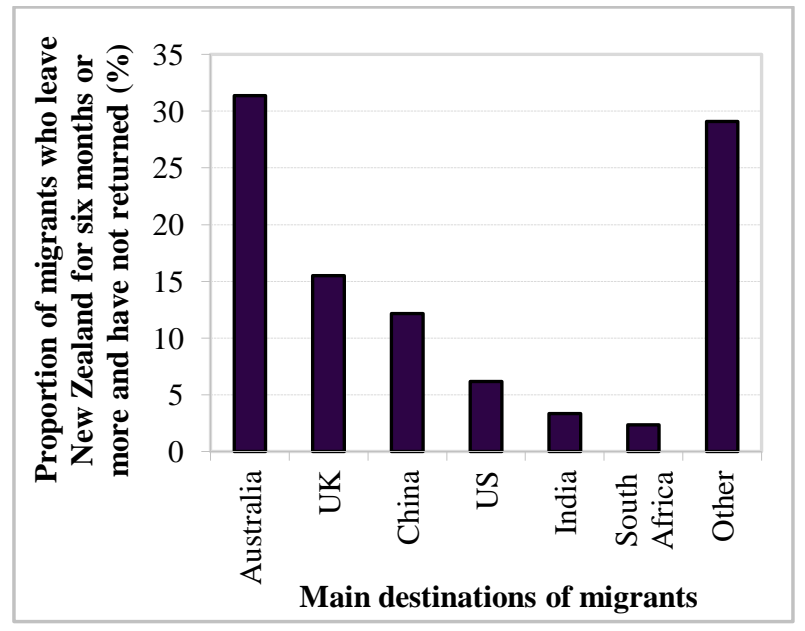

Fifteen percent moved to the United Kingdom, 12 percent to China, 6 percent to the United States, 3 percent to India, and 2 percent to South Africa. Apart from migrants moving to Australia, some of these migrants returned to their home countries after spending some time in New Zealand.

Figure 6 shows the destinations of the 121,484 migrants, who had left New Zealand by the end of the study period, from the main source countries.

Figure 6: Destinations of migrants from the main source countries

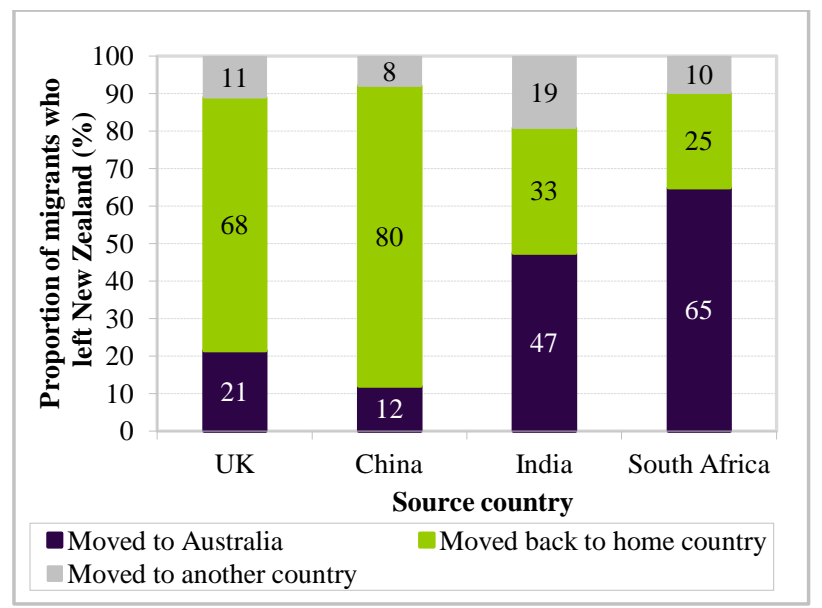

Of the migrants who took up residence from the United Kingdom, 13,395 had left New Zealand by the end of the study period. Two-thirds of these migrants moved back to the United Kingdom, on average, after two and a half years in New Zealand. This finding is similar to results from Australia (Burrows and Holmes 2011), which estimated that around 59 percent of recent migrants in Australia from the United Kingdom returned to the United Kingdom.

Of the migrants from the United Kingdom who returned home, 75 percent were approved under the Skilled/Business Stream and 18 percent under the Uncapped Family Stream.

For migrants who took up residence from China, 9,687 had left New Zealand by the end of the study period. Most (80 percent) of these migrants moved back to China, on average, two years after taking up residence in New Zealand.

Of the migrants from China who moved back to China, 70 percent were approved under the Skilled/Business Stream. These were most likely to be young Chinese who came to study and get work experience in New Zealand before returning to work and settle in China because 55 percent were aged 20-39 at the time of their return.

For migrants who took up residence from India, 6,411 had left New Zealand by the end of the study period. Almost half of these migrants moved on to Australia, on average, after about five years since taking up residence in New Zealand.

Most (83 percent) of the migrants from India who moved on to Australia were approved under the Skilled/Business Stream, but 13 percent were approved under the Uncapped Family Stream. Therefore, these migrants were likely to be skilled migrants who moved with their families to Australia.

For migrants who took up residence from South Africa, 5,610 had left New Zealand by the end of the study period. Most of these migrants (65 percent) moved on to Australia and they were mainly skilled migrants. About one in four migrants from South Africa had returned to South Africa by the end of the study period.

\section{Skills of migrants who left New Zealand}

Skilled migrants come to New Zealand through the SMC. This points-based immigration policy is designed to ensure migrants have the skills, qualifications, and work experience that New Zealand needs.

Occupation is used as a proxy for skill level to illustrate the skills lost with the movement of people out of New Zealand. Appendix Table A3 lists the top 10 occupations for migrants who moved to Australia, the United Kingdom, and the United States.

The main skills being lost from migrants who moved on to Australia, the United Kingdom, and the United States are managers, professionals, and technicians. Nursing and midwifery professionals, specialised managers, and architects, engineers, and related professionals are in the top three occupations of migrants lost to Australia and the United Kingdom. In addition, some of the skills lost to 
the United States are in the entertainment industry and professionals associated with sports and religion.

\section{Mobility of the New Zealand-born population}

The focus of this report is on the mobility patterns of migrants who took up residence in New Zealand, but it is also important to consider these patterns in conjunction with the mobility patterns of the New Zealand-born population. This section discusses the mobility patterns of the New Zealand-born population who travelled from 1 January 1998 to 31 December 2011.

\section{New Zealand-born population who moved out of New Zealand}

During the study period, 909,840 of the New Zealandborn population moved out of New Zealand for a period of six months or more.

Figure 7 shows the age distribution of the New Zealandborn population who moved out of New Zealand for a period of six months or more, where age is taken at the first time a person travels during the study period.

Figure 7: Age distribution of the New Zealand-born population who moved out of New Zealand for six months or more

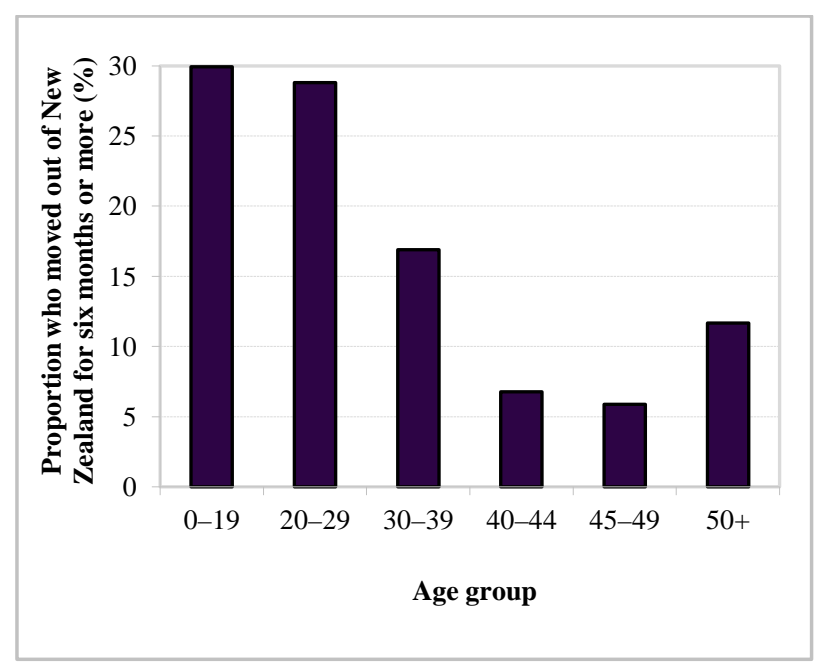

More than half the New Zealand-born population who moved out of New Zealand for a period of six months or more was aged under 30. This finding reflects the intentions of many young New Zealanders to get overseas experience before returning and settling down in New Zealand (Milne et al. 2001).

\section{New Zealand-born population who left New Zealand}

Overall, 67 percent $(609,684)$ of the New Zealand-born population who moved out for six months or more had not returned by the end of the study period. While it is usual for young New Zealanders to go on overseas experience, many do come back, having acquired valuable skills and experience during their time working and travelling overseas. This is evident in Figure 8 where a smaller proportion of the New Zealand-born population aged 20-29 had not returned to New Zealand compared with other age groups.

Figure 8: New Zealand-born population who had moved out and not returned by the end of the study period

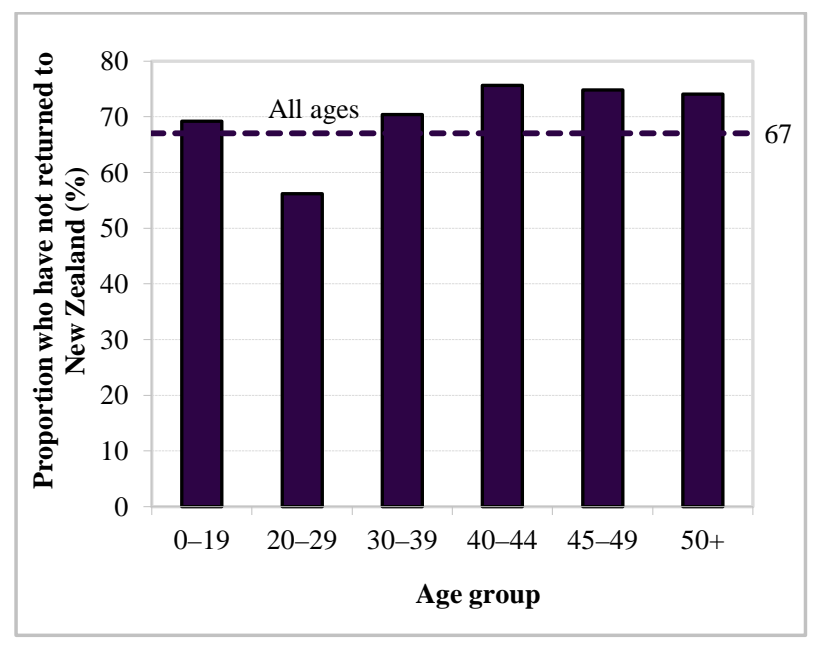

\section{Destinations of the New Zealand-born population who left New Zealand}

As noted above 609,684 of the New Zealand-born population who moved away from New Zealand for six months or more had not returned by the end of the study period. Figure 9 shows the main destinations for this group.

Figure 9: Main destinations of the New Zealand-born population

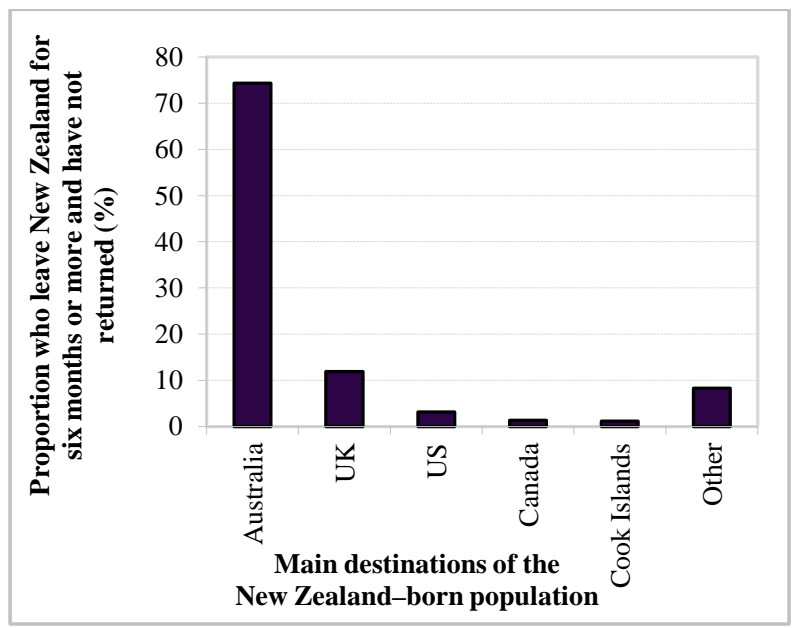

Australia is the main destination with 74 percent of the New Zealand-born population who had settled overseas. This is consistent with the results of Bryant and Law (2004) who estimated that over 75 percent of the New Zealand-born population living overseas were in Australia as of 2001. Furthermore, results from Statistics 
New Zealand for PLT departures in 2011 show that 76 percent of New Zealand citizens moved to Australia (Statistics New Zealand 2012). Some of the migrants would have obtained New Zealand citizenship and have been included in the Statistics New Zealand results for PLT departures.

The large proportion of the New Zealand-born population moving to Australia reflects the physical proximity of Australia and the privileged position of New Zealand citizens under the 1973 TTTA, which stipulates that New Zealand and Australian citizens may travel, work, and live in either country without being required to apply for entry permission.

Twelve percent of the New Zealand-born population moved to the United Kingdom, 3 percent to the United States, and 1 percent each to Canada and the Cook Islands.

\section{Skills of the New Zealand-born population who left New Zealand}

For the New Zealand-born population, Appendix Table A4 shows the top 10 occupations for those who had left for Australia, the United Kingdom, or the United States by the end of the study period.

The main occupations associated with the New Zealandborn population who moved to Australia were managers, nursing and midwifery professionals, and finance and sales-associated professionals. However, lower-skilled occupations were probably attracted to the Australian economy's demand for services in the transport, building, and hospitality industries. This is in line with the results of Haig (2010), which show that the New Zealand-born population in Australia is more likely to work in lowerskilled occupations than those in New Zealand, using 2006 census data from Australia and New Zealand. That study also noted that mining and construction were the industries with the highest relative share of the New Zealand-born population working in Australia.

Teachers (primary and early childhood), managers, computing professionals, and professionals associated with entertainment and sports are common occupations among the New Zealand-born population that moved to the United Kingdom or United States.

\section{Conclusions}

Migration plays a significant role in the New Zealand labour market and economy, so it is important that New Zealand ensures migrants are settled well and facilitates their retention in the longer term. Nonetheless, migration is no longer a permanent decision nor it is a one-off movement between the migrant's source and destination countries. Migrants may return to their source countries or move on to another country. Even repeat or circular migration between the source and destination countries is common among migrants.
This study identifies the retention rates of migrants who took up residence in New Zealand and the subsequent mobility patterns of those who moved out of New Zealand. The mobility patterns of the New Zealandborn population are also identified.

The findings in this study will provide additional evidence for the Labour Group in the Ministry of Business, Innovation and Employment when reviewing important policies to improve the economic and social outcomes from immigration. In addition, these findings can potentially inform the development of new immigration and settlement policies for different groups of immigrants.

\section{Implications for settlement of migrants}

New Zealand's migrant retention rate appears reasonably high, although in the absence of international data it is difficult to compare New Zealand to other migrantreceiving countries. However, this evidence provides a basis for understanding the extent of retention and onward migration of migrants to New Zealand.

This study draws attention to the mobility of skilled migrants, which is important in the context of the global competition for skills. While skilled migration is the focus of New Zealand's attraction strategies, these migrants have skills in demand and are therefore more likely to leave New Zealand than other migrant groups.

Australia is a common destination for migrants who leave New Zealand (31 percent of those who leave), but it is much more so for New Zealanders who leave (74 percent of departures). Within the migrant population, there seems to be a strong element of circular migration among the main source countries, particularly the United Kingdom and China.

Recent research suggests that circular migration (of both permanent and temporary migrants) can be viewed as a triple-win solution for migrants' source countries, migrants' destination countries and the migrants themselves (Agunias and Newland 2007). Migrant destination countries benefit through meeting their labour market shortages; migrant source countries benefit through the skills and resources of returning migrants; and migrants themselves benefit by taking advantage of more openings for legal migration.

This study showed that some migrants appear to leave New Zealand relatively soon after gaining residence. Migrants leave New Zealand for a range of reasons, only some of which may be related to migrants' unrealistic expectations of living and working in New Zealand. While an early departure would represent a significant cost to migrants, it is possible some of these migrants would have spent a significant period in New Zealand as temporary workers or students before gaining residence. Further work to understand these particular outcomes will inform our targeting of settlement support and interventions. 
The main focus of this study was on the retention of migrants, but it also adds to our understanding of the dynamics of Trans-Tasman migration. While it is difficult to compare the mobility of migrants to New Zealandborn, it is useful to draw comparisons between the skill compositions of Trans-Tasman migrants. This work supports other research that shows a broader skill range in the migration of New Zealand-born to Australia than migrants.

\section{Notes}

1. Access to the data used in this study was provided by Statistics New Zealand under conditions designed to give effect to the security and confidentiality provisions of the Statistics Act 1975. The results in this paper are the work of the authors, not Statistics New Zealand.

\section{References}

Agunias, D. and Newland, K. (2007). Circular Migration and Development: Trends, Policy Routes, and Ways Forward. Washington DC: Migration Policy Institute.

Bryant, J. and Law, D. (2004). New Zealand's Diaspora and Overseas-born Population. Working Paper 04/13. Wellington: The Treasury.

Burrows, R. and Holmes, M. (2011). Ping-Pong Poms? Emotional reflexivity in contemporary return migration from Australia to the UK. Australian Journal of Social Issues (yet to be published).

Department of Labour (2011). Migration Trends and Outlook 2010-2011. Wellington: Department of Labour.

Department of Labour (2012). Permanent and Long Term Migration: The Big Picture. Wellington: Department of Labour.

Haig, R. (2010). Working across the Ditch: New Zealanders in Australia. Wellington: Department of Labour.
Hoadley, S. (2002). NZ-Australia Relations: Moving Together or Drifting Apart? Papers for the $36^{\text {th }}$ Otago Foreign Policy School. In Catley, B. (2002). Trans-Tasman Migration: Issues and Politics. Wellington: Dark Horse Publishing.

Masgoret, A-M., Merwood, P. and Tausi, M. (2009). New Faces, New Futures: New Zealand. Findings from the Longitudinal Survey: New Zealand (LisNZ) - wave one. Wellington: Department of Labour.

Milne, B.J., Poulton, R., Caspi, A. and Moffitt. T.E. (2001). Brain drain or OE? Characteristics of young New Zealanders who leave. New Zealand Medical Journal, 114(1141), 450-453.

Newland, K., Agunias, D. and Terrazas, A. (2008). Learning by Doing: Experiences of Circular Migration. Washington DC: Migration Policy Institute.

Papadopoulos, T. (2012) Who Left, Who Returned and Who Was Still Away? Migration patterns of 2003 graduates, 2004-2010. Wellington: Ministry of Business, Innovation and Employment.

Sanderson, L. (2009). International mobility of new migrants to Australia. International Migration Review, 43, 292-331.

Shorland, P. (2006). People on the Move: A study of migrant movement patterns to and from New Zealand. Wellington: Department of Labour.

Statistics New Zealand (2012). International Travel and Migration: December 2011. Hot Off the Press. Wellington: Statistics New Zealand.

Stillman, S. (2011). Labour market outcomes for immigrants and the New Zealand-born 19972009. Wellington: Department of Labour.

Tausi, M. (2012) Migrants in New Zealand: Retention and onward migration, 1998-2011. Wellington: Ministry of Business, Innovation and Employment. 


\section{Appendix}

Table A1: All movements for migrants and the New Zealand-born population

\begin{tabular}{|c|c|c|c|c|}
\hline \multirow{2}{*}{$\begin{array}{l}\text { Time in or out of New } \\
\text { Zealand }\end{array}$} & \multicolumn{2}{|l|}{ Arrivals } & \multicolumn{2}{|l|}{ Departures } \\
\hline & Number & $\begin{array}{l}\text { Percent } \\
\text { (\%) }\end{array}$ & Number & $\begin{array}{l}\text { Percent } \\
(\%)\end{array}$ \\
\hline \multicolumn{5}{|l|}{ Migrants } \\
\hline Less than 6 months & $1,056,801$ & 49.0 & $1,828,278$ & 92.1 \\
\hline 6-11 months & 461,688 & 21.4 & 80,721 & 4.1 \\
\hline 12-23 months & 351,852 & 16.3 & 45,885 & 2.3 \\
\hline 24 months or more & 288,537 & 13.4 & 31,086 & 1.6 \\
\hline Total & $2,158,881$ & 100.0 & $1,985,970$ & 100.0 \\
\hline \multicolumn{5}{|l|}{$\begin{array}{l}\text { New Zealand-born } \\
\text { population }\end{array}$} \\
\hline Less than 6 months & $7,415,568$ & 60.2 & $11,807,139$ & 86.3 \\
\hline 6-11 months & $2,137,296$ & 17.3 & 871,071 & 6.4 \\
\hline 12-23 months & $1,578,843$ & 12.8 & 618,816 & 4.5 \\
\hline 24 months or more & $1,193,286$ & 9.7 & 383,679 & 2.8 \\
\hline Total & $12,324,993$ & 100.0 & $13,680,708$ & 100.0 \\
\hline
\end{tabular}


Table A2: Characteristics of migrants who took up residence in New Zealand

\begin{tabular}{|c|c|c|c|}
\hline Characteristic & $\begin{array}{l}\text { Migrants who moved } \\
\text { out of New Zealand } \\
\text { for six months or more } \\
\text { since residence uptake } \\
(\%)\end{array}$ & $\begin{array}{l}\text { Migrants who } \\
\text { remained in New } \\
\text { Zealand since } \\
\text { residence uptake (\%) }\end{array}$ & $\begin{array}{l}\text { Migrants who took up } \\
\text { residence (\%) }\end{array}$ \\
\hline \multicolumn{4}{|l|}{ Gender ${ }^{(1)}$} \\
\hline Male & 49.5 & 48.4 & 48.7 \\
\hline Female & 50.5 & 51.6 & 51.3 \\
\hline \multicolumn{4}{|l|}{ Residence approval stream } \\
\hline Skilled/Business & 63.5 & 57.5 & 59.2 \\
\hline Uncapped Family Stream & 17.1 & 21.4 & 20.2 \\
\hline Capped Family Stream & 14.4 & 11.9 & 12.6 \\
\hline International/Humanitarian & 5.0 & 9.2 & 8.0 \\
\hline \multicolumn{4}{|l|}{ Source country } \\
\hline United Kingdom & 17.2 & 20.3 & 19.4 \\
\hline China & 18.4 & 11.1 & 13.1 \\
\hline India & 11.2 & 9.1 & 9.7 \\
\hline South Africa & 6.8 & 9.6 & 8.8 \\
\hline Other & 46.4 & 49.9 & 49.0 \\
\hline \multicolumn{4}{|l|}{ Previous Visa } \\
\hline None & 65.2 & 47.1 & 52.1 \\
\hline Student visa only & 7.4 & 11.2 & 10.1 \\
\hline Student and work visa & 5.7 & 8.0 & 7.4 \\
\hline Work visa only & 21.7 & 33.7 & 30.4 \\
\hline Total number of migrants & 161,895 & 416,088 & 577,983 \\
\hline
\end{tabular}

(1) Excludes migrants with no gender recorded 
Figure A1: Movements of migrants who took up residence in New Zealand, 1 January 1998 to 31 December 2011

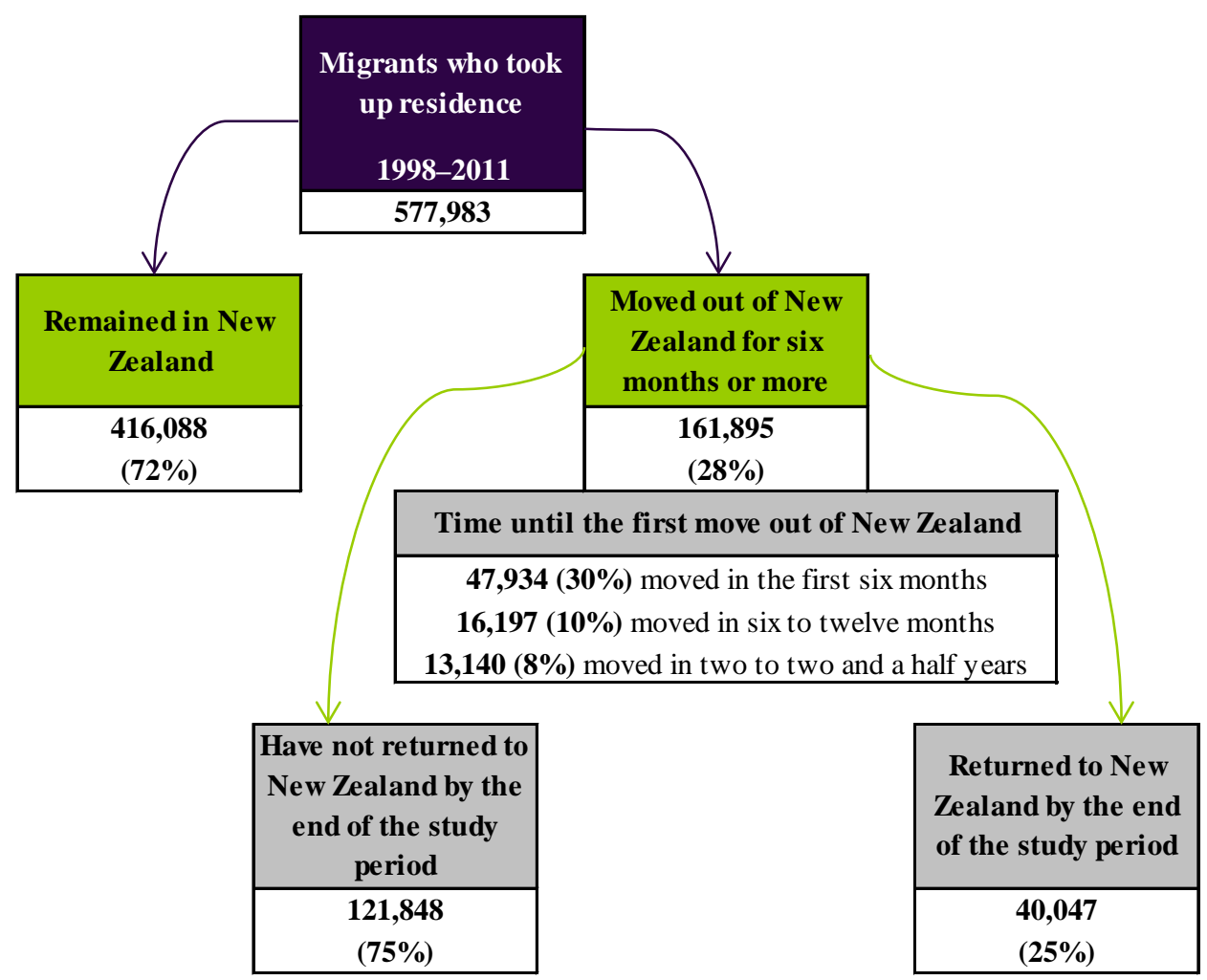

Table A3: Occupation of migrants who moved to Australia, the United Kingdom, and the United States

Top 10 occupations of migrants who moved to:

\begin{tabular}{|c|c|c|}
\hline Australia & United Kingdom & United States of America \\
\hline $\begin{array}{l}\text { Nursing and Midwifery } \\
\text { Professionals }\end{array}$ & Specialised Managers & Specialised Managers \\
\hline Specialised Managers & $\begin{array}{l}\text { Nursing and Midwifery } \\
\text { Professionals }\end{array}$ & Computing Professionals \\
\hline $\begin{array}{l}\text { Architects, Engineers and } \\
\text { Related Professionals }\end{array}$ & $\begin{array}{l}\text { Architects, Engineers and } \\
\text { Related Professionals }\end{array}$ & Tertiary Teaching Professionals \\
\hline Computing Professionals & $\begin{array}{l}\text { Secondary Teaching } \\
\text { Professionals }\end{array}$ & General Managers \\
\hline $\begin{array}{l}\text { Health Professionals (Except } \\
\text { Nursing) }\end{array}$ & Computing Professionals & $\begin{array}{l}\text { Health Professionals (Except } \\
\text { Nursing) }\end{array}$ \\
\hline $\begin{array}{l}\text { Physical Science and } \\
\text { Engineering Technicians }\end{array}$ & $\begin{array}{l}\text { Health Professionals (Except } \\
\text { Nursing) }\end{array}$ & $\begin{array}{l}\text { Writers, Artists, Entertainment } \\
\text { and Sports Associate } \\
\text { Professionals }\end{array}$ \\
\hline General Managers & Business Professionals & $\begin{array}{l}\text { Architects, Engineers and } \\
\text { Related Professionals }\end{array}$ \\
\hline Machinery Mechanics and Fitters & $\begin{array}{l}\text { Building Frame and Related } \\
\text { Trades Workers }\end{array}$ & Business Professionals \\
\hline Business Professionals & General Managers & $\begin{array}{l}\text { Nursing and Midwifery } \\
\text { Professionals }\end{array}$ \\
\hline Electricians & Machinery Mechanics and Fitters & Religious Professionals \\
\hline
\end{tabular}


Table A4: Occupation of the New Zealand-born population who moved to Australia, the United Kingdom, and the United States

\begin{tabular}{|c|c|c|}
\hline \multicolumn{3}{|c|}{ Top 10 occupations of the New Zealand-born population who moved to: } \\
\hline Australia & United Kingdom & United States of America \\
\hline Specialised Managers & $\begin{array}{l}\text { Primary and Early Childhood } \\
\text { Teaching Professionals }\end{array}$ & Specialised Managers \\
\hline $\begin{array}{l}\text { Housekeeping and Restaurant } \\
\text { Services Workers }\end{array}$ & Business Professionals & $\begin{array}{l}\text { Primary and Early Childhood } \\
\text { Teaching Professionals }\end{array}$ \\
\hline Salespersons and Demonstrators & Specialised Managers & $\begin{array}{l}\text { Writers, Artists, Entertainment } \\
\text { and Sports Associate } \\
\text { Professionals }\end{array}$ \\
\hline Motor Vehicle Drivers & Legal Professionals & $\begin{array}{l}\text { Nursing and Midwifery } \\
\text { Professionals }\end{array}$ \\
\hline Labourers & $\begin{array}{l}\text { Writers, Artists, Entertainment } \\
\text { and Sports Associa }\end{array}$ & Computing Professionals \\
\hline $\begin{array}{l}\text { Building Frame and Related } \\
\text { Trades Workers }\end{array}$ & $\begin{array}{l}\text { Finance and Sales Associate } \\
\text { Professionals }\end{array}$ & Business Professionals \\
\hline $\begin{array}{l}\text { Building Finishers and Related } \\
\text { Trades Workers }\end{array}$ & Salespersons and Demonstrators & Salespersons and Demonstrators \\
\hline Library, Mail and Related Clerks & $\begin{array}{l}\text { Housekeeping and Restaurant } \\
\text { Services Workers }\end{array}$ & $\begin{array}{l}\text { Housekeeping and Restaurant } \\
\text { Services Workers }\end{array}$ \\
\hline $\begin{array}{l}\text { Nursing and Midwifery } \\
\text { Professionals }\end{array}$ & Computing Professionals & Library, Mail and Related Clerks \\
\hline $\begin{array}{l}\text { Finance and Sales Associate } \\
\text { Professionals }\end{array}$ & $\begin{array}{l}\text { Nursing and Midwifery } \\
\text { Professionals }\end{array}$ & $\begin{array}{l}\text { Building Frame and Related } \\
\text { Trades Workers }\end{array}$ \\
\hline
\end{tabular}

